\title{
PENGARUH RASIO KEUANGAN TERHADAP DIVIDEND PAYOUT RATIO PADA PERUSAHAAN SEKTOR TRADE, SERVICE AND INVESTMENT YANG TERDAFTAR DI BEI
}

\author{
Erinta Sijabat $^{1)}$, Siti Sara ${ }^{2}$, Putri Husyada Fi'lma ${ }^{3)}$, Febti Latreia Missi ${ }^{4}$, D.Sakuntala ${ }^{5}$. \\ Fakultas Ekonomi, Universitas Prima Indonesia \\ erinta30sijabat@gmail.com¹, Sarahsunda@icloud.com², putri.husyada88@gmail.com³, \\ kristinawartisinaga10@yahoo.com ${ }^{4}$,dw1t4@yahoo.com ${ }^{5}$
}

\begin{abstract}
This study aims to determine the financial ratios represented by the liquidity ratio, activity ratio, solvency ratio, profitability ratio to dividend payout ratio. Data collection techniques using purposive sampling and obtained as many as 21 samples of companies from 132 populations of companies in the trade, service, and investment sectors listed on the Indonesia Stock Exchange (BEI). The analysis technique uses multiple linear regression. Based on the results of the coefficient test, the $R$ square value of 0.141 indicates that the correlation or closeness of the relationship between the liquidity ratio, activity ratio, solvency ratio, profitability ratio and dividend payout ratio is only 14.1\%. The Adjusted $R$ Square value of 0.097 indicates that the liquidity ratio, activity ratio, solvency ratio, profitability ratio explains the variable to the dividend payout ratio of $9.7 \%$. The F test shows that the value of Fcount $>$ Ftable $(3,235>2.49)$ so that simultaneously the quick ratio, Total Asset Turn Over, Debt to Asset Ratio, Return On Equity have an effect on the dividend payout ratio in companies in the trade, service and investment sectors. In the t test results, only the Profitability Ratio (Return On Equity) variable has a positive and significant effect on the dividend payout ratio, which is 0.048 .
\end{abstract}

Keywords: liquidity ratio, activity ratio, solvency ratio, profitability ratio and dividend payout ratio

\section{PENDAHULUAN}

Pasar modal merupakan tempat bagi investor menginvestasikan dana untuk memperoleh dividen. Dividen merupakan keuntungan yang dibagikan perusahaan kepada para investor. Kebijakan dividen mempunyai dampak yang sangat penting bagi para investor maupun bagi perusahaan. Keputusan memberikan dividen kepada pemegang saham melibatkan dua pihak yang berbeda kepentingan yaitu antara perusahaan dan investor. Permasalahan yang paling sering muncul dalam kebijakan dividen ini adalah satu sisi perusahaan memiliki keinginan membagi dividen kepada investor dalam jumlah yang kecil sehingga sebagian laba dapat ditahan dalam perusahaan, karena salah satu sumber dana yang paling penting untuk membiayai pertumbuhan perusahaan adalah laba ditahan, namun di sisi lain pihak investor menginginkan dividen yang besar.

Dalam membagikan dividen ada empat faktor yang harus diperhatikan yaitu faktor aktiva lancar tanpa memperhitungkan nilai persediaan (inventori) karena disini dapat dilihat bagaimana posisi kas dalam sebuah perusahaan yang harus dipertimbangkan sebelum sebuah perusahaan membuat keputusan dalam menentukan seberapa besar dividen yang akan dibayarkan kepada para pemegang saham, faktor penjualan (sales) karena penjualan yang tinggi akan mencerminkan kinerja perusahaan secara finansial. Semakin tinggi penjualan perusahaan berarti semakin tinggi kemampuan perusahaan dalam membagikan dividennya, faktor berikutnya adalah total utang karena jika dalam sebuah perusahaan total utang yang terlalu tinggi akan memberikan dampak yang kurang baik terhadap perusahaan karena perusahaan tersebut harus membayar kewajiban-kewajibannya. Yang artinya semakin tinggi total utang maka akan semakin kecil dividen yang akan dibagikan kepada para pemegang saham karena kewajiban untuk membayar utang lebih diutamakan dari pada pembagian dividen dan faktor laba bersih setelah pajak dimana tujuan utama didirikannya sebuah perusahaan adalah untuk memperoleh laba (profit). Laba bersih setelah pajak menjadi salah satu perhatian investor karena akan menjadi tolak ukur bagaimana perusahaan tersebut mampu bertahan dalam bisnisnya. 
Semakin tinggi tingkat laba (profit) yang didapat sebuah perusahaan maka kemungkinan pembagian dividen akan semakin besar.

Dari latar belakang yang telah dibahas sebelumnya maka peneliti tertarik membahas lebih mendalam dengan judul "Pengaruh Rasio Keuangan terhadap Dividend Payout Ratio pada Perusahaan Sektor Trade, Service, and Investmentyang terdaftar di Bursa Efek Indonesia".

\section{KAJIAN LITERATUR}

Likuiditas merupakan indikator kemampuan perusahaan membayar semua kewajiban finansial dalam jangka pendek pada saat jatu tempo dengan menggunakan aktiva lancar yang tersedia. (Syamsuddin, 2018:41). Rasio likuiditas mengukur kemampuan likuiditas jangka pendek perusahaan dengan melihat aktiva lancar perusahan relatif terhadap utang lancarnya. (Hanafi\&Halim, 2012:75)

Rasio aktivitasmenggambarkan aktivitas yang dilakukan perusahaan dalam menjalankan operasinya baik dalam kegiatan penjualan, pembelian, dan kegiatan lainnya. (Harahap, 2015:308). Rasio Aktivitas merupakan rasio yang mengukur efektivitas perusahaan dalam mengelola aset agar menghasilkan penjualan.(Wijaya, 2017:32)

Rasio solvabilitas menggambarkan kemampuan perusahaan melunasi kewajiban jangka panjangapabila perusahaan dilikuidasi.(Sjahrial dan Purba, 2013:37). Rasio Solvency (leverage) adalah rasio untuk mengukur kemampuan perusahaan melunasi utangnya. Utang dapat dibandingkan dengan asset atau modal sendiri.(Prihadi ,2012:167)

Rasio profitabilitas merupakan rasio untuk menilai kemampuan perusahaan mencari keuntungan. Rasio ini memberikan ukuran tingkat efektivitas manajemen suatu perusahaan.(Kasmir, 2015:196). Rasio profitabilitas ialah kemampuan manajemen untuk memperoleh laba. Untuk memperoleh laba di atas rata-rata, manajemen harus mampu meningkatkan pendapatan (revenue).(Utari, Dewi dkk, 2014:63)

\section{Tabel 2.1 Penelitian Terdahulu}

\begin{tabular}{|c|c|c|c|c|}
\hline No & $\begin{array}{l}\text { Nama dan } \\
\text { Tahun } \\
\text { Penelitian }\end{array}$ & Judul & Variabel & Hasil Penelitian \\
\hline 1. & $\begin{array}{l}\text { Haryatih, } \\
2015\end{array}$ & $\begin{array}{lr}\text { Pengaruh } & \text { Growth, } \\
\text { Cash } & \text { Position, } \\
\text { Liquidity,Solvability, } \\
\text { dan Profitability, } \\
\text { Terhadap Dividen } \\
\text { Payout Ratio. }\end{array}$ & $\begin{array}{l}\text { Independen: } \\
\text { Growth, Cash } \\
\text { Position, } \\
\text { Liquidity, } \\
\text { Solvability, dan } \\
\text { Profitability } \\
\text { Dependen: } \\
\text { Dividen payout } \\
\text { ratio }\end{array}$ & $\begin{array}{l}\text { Growth, Cash } \\
\text { Position, } \\
\text { Liquidity (CR), } \\
\text { Solvability } \\
\text { (DER), dan } \\
\text { profitability } \\
\text { (ROE), secara } \\
\text { bersama-sama } \\
\text { berpengaruh } \\
\text { signifikan } \\
\text { terhadap Dividen } \\
\text { Payout ratio }\end{array}$ \\
\hline 2. & $\begin{array}{l}\text { Purnami, } \\
\text { K. D. A. } \\
\text { Dan } \\
\text { Artini, L. } \\
\text { G. S. } 2016\end{array}$ & $\begin{array}{lr}\text { Pengaruh } & \text { Investment } \\
\text { Opportunity Set, Total } \\
\text { Asset Turn } & \text { Over dan } \\
\text { Sales } & \text { Growth } \\
\text { Terhadap } & \text { Kebijakan } \\
\text { Dividen. } & \end{array}$ & $\begin{array}{l}\text { Independen: } \\
\text { Pengaruh Investment } \\
\text { Opportunity } \\
\text { Set,Total Asset } \\
\text { Overdarn } \\
\text { Growth } \\
\\
\text { Dependen: } \\
\text { Kebijakan } \\
\text { Dividen }\end{array}$ & $\begin{array}{l}\text { Total Asset Turn } \\
\text { Over berpengaruh } \\
\text { positif dan } \\
\text { signifikan } \\
\text { terhadap } \\
\text { Kebijakan } \\
\text { Dividen }\end{array}$ \\
\hline
\end{tabular}




\begin{tabular}{|c|c|c|c|c|}
\hline 3. & $\begin{array}{l}\text { Sarmento, } \\
\text { J. D. C. } \\
\text { Dan Dana, } \\
\text { Made. } \\
2016\end{array}$ & $\begin{array}{lr}\text { Pengaruh Return on } \\
\text { Equity, Current Ratio, } \\
\text { and Earning Per } \\
\text { Share } & \text { Terhadap } \\
\text { Kebijakan } & \text { Dividen } \\
\text { Pada } & \text { Perusahaan } \\
\text { Keuangan } & \end{array}$ & $\begin{array}{l}\text { Independen: } \\
\text { Return on Equity, } \\
\text { Current Ratio, } \\
\text { and Earning Per } \\
\text { Share } \\
\text { Dependen: } \\
\text { Kebijakan } \\
\text { Dividen }\end{array}$ & $\begin{array}{l}\text { Hasil Uji t Variabel } \\
\text { return on equity } \\
\text { menunjukkan bahwa } \\
\text { return on equity } \\
\text { (ROE) berpengaruh } \\
\text { positif namun tidak } \\
\text { signifikan terhadap } \\
\text { kebijakan dividen } \\
\text { (dividend payout } \\
\text { ratio). }\end{array}$ \\
\hline
\end{tabular}

Berdasarkan uraian teori-teori diatas maka peneliti membuat kerangka konseptual yang dapat dilihat pada gambar 2.1:

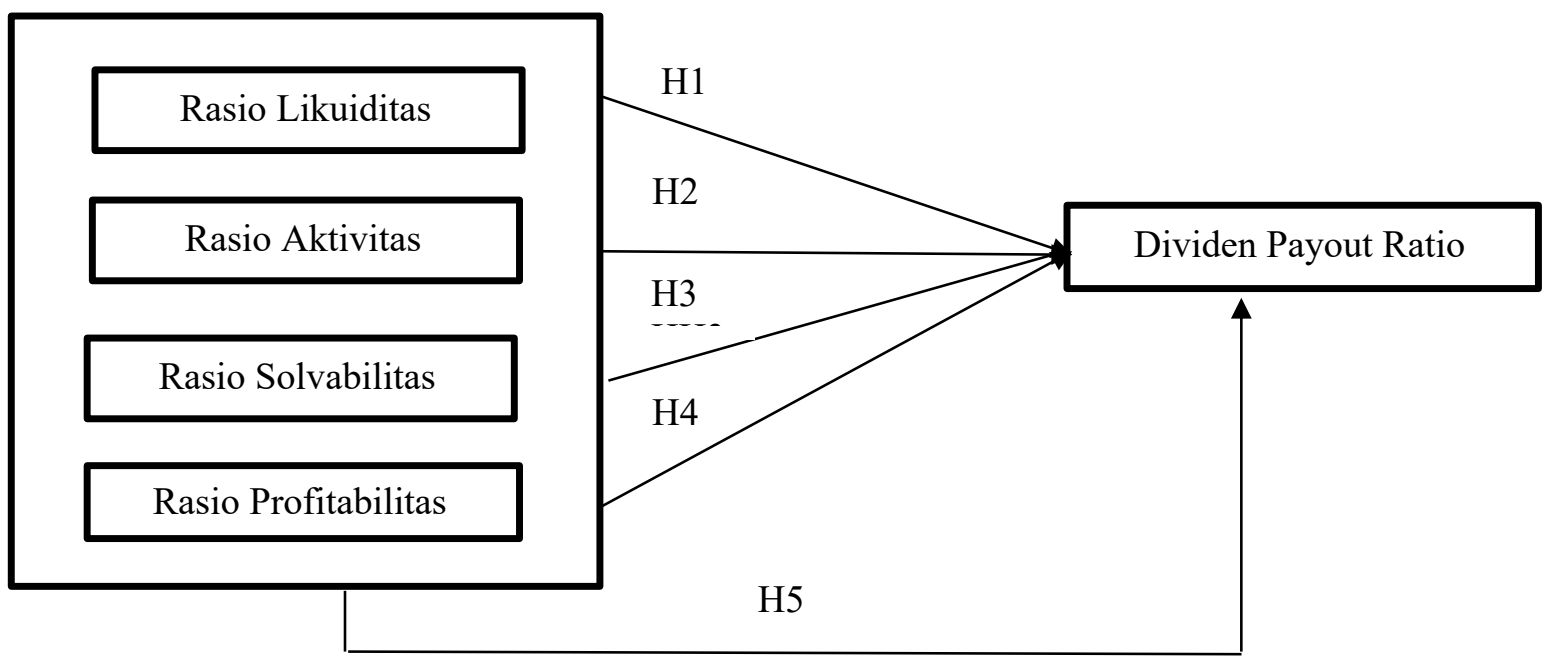

H1 : Rasio Likuiditas berpengaruh tehadap Dividend Payout RatioPada Perusahaan di Sektor Trade, Service, And Investment yang ada di BEI Periode 2015-2018.

H2 : Rasio Aktivitas berpengaruh tehadap Dividend Payout RatioPada Perusahaan di Sektor Trade, Service, And Investment yang ada di BEI Periode 2015-2018.

H3 : RasioSolvabilitas berpengaruh terhadap Dividend Payout RatioPada Perusahaan di Sektor Trade, Service, And Investment yang ada di BEI Periode 2015-2018.

H4 : RasioProfitabilitas berpengaruh terhadap Dividend Payout RatioPada Perusahaan di Sektor Trade, Service, And Investment yang ada di BEI Periode 2015-2018.

H5 : Rasio Likuiditas, Rasio Aktivitas, Rasio Solvabilitas dan Rasio Profitabilitas berpengaruh terhadap Dividend Payout RatioPada Perusahaan di Sektor Trade, Service, And Investment yang ada di BEI Periode 2015-2018.

\section{METODE}

Pendekatan penellitian yang digunakan dalam penelitian ini adalah pendekatan penelitian kuantitatif. Jenis penelitian yang digunakan pada penelitian ini adalah statistik deskriptif. Populasi dalam penelitian ini ialah perusahaan sektor trade, service, and investment yang sudah terdaftar pada Bursa Efek Indonesia periode 2015 - 2018 sebanyak 132 perusahaan. Penarikan sampel menggunakan teknik purposive sampling. Purposive sampling adalah memilih sampel dari populasi yang didasarkan pada beberapa pertimbangan tertentu, yang dimana baik itu pertimbangan ahli ataupun pertimbangan ilmiah. (Juliandi\&Irfan 2013:58). 
Tabel 2. Kriteria Pemilihan Sampel

\begin{tabular}{|c|l|c|}
\hline NO & \multicolumn{1}{|c|}{ Kriteria } & Jumlah \\
\hline 1 & $\begin{array}{l}\text { Perusahaan Sektor Trade, Service, and Investment yang } \\
\text { terdaftar di BEI periode 2015-2018. }\end{array}$ & 132 \\
\hline 2 & $\begin{array}{l}\text { Perusahaaan Sektor Trade, Service, and Investment } \\
\text { yang mempublish laporan keuangan audit dan lengkap } \\
\text { periode 2015-2018. }\end{array}$ & 97 \\
\hline 3 & $\begin{array}{l}\text { Perusahaaan Sektor Trade, Service, and Investment } \\
\text { yang mempublish laporan keuangan dalam satuan } \\
\text { Rupiah periode 2015-2018. }\end{array}$ & 123 \\
\hline 4 & $\begin{array}{l}\text { Perusahaaan Sektor Trade, Service, and Investment } \\
\text { yang memiliki laba periode 2015-2018. }\end{array}$ & 96 \\
\hline 5 & $\begin{array}{l}\text { Perusahaaan Sektor Trade, Service, and Investment } \\
\text { yang membagikan Dividen periode 2015-2018. }\end{array}$ & 30 \\
\hline
\end{tabular}

Dari kriteria diatas didapat sampel sebanyak 21 perusahaan dengan periode waktu 4 tahun, sehingga jumlah data $21 \times 4=84$ data.

Tabel 3. Definisi Operasional Variabel Penelitian

\begin{tabular}{|c|c|c|}
\hline Variabel & Definisi & Indikator \\
\hline $\begin{array}{l}\text { Rasio } \\
\text { Aktivitas }\end{array}$ & $\begin{array}{l}\text { Rasio Likuiditas mengukur } \\
\text { kemampuan likuiditas jangka pendek } \\
\text { perusahaan dengan melihat aktiva } \\
\text { lancar perusahan relatif terhadap utang } \\
\text { lancarnya.. }\end{array}$ & $\begin{array}{l}\text { Quick Ratio } \\
=\frac{\text { Current Assets }- \text { Inventory }}{\text { Current Liabilities }}\end{array}$ \\
\hline $\begin{array}{l}\text { Rasio } \\
\text { Aktivitas }\end{array}$ & $\begin{array}{l}\text { Rasio Aktivitas merupakan rasio yang } \\
\text { mengukur efektivitas perusahaan dalam } \\
\text { mengelola aset agar menghasilkan } \\
\text { penjualan. }\end{array}$ & TATO $=\frac{\text { Penjualan Bersih }}{\text { Total Aktiva }}$ \\
\hline $\begin{array}{l}\text { Rasio } \\
\text { Solvabilitas }\end{array}$ & $\begin{array}{l}\text { Rasio Solvency (leverage) adalah rasio } \\
\text { untuk mengukur kemampuan } \\
\text { perusahaan melunasi utangnya. Utang } \\
\text { dapat dibandingkan dengan asset atau } \\
\text { modal sendiri. }\end{array}$ & $\mathrm{DAR}=\frac{\text { Total } D e b t}{\text { Total Asset }}$ \\
\hline $\begin{array}{l}\text { Rasio } \\
\text { Profitabilitas }\end{array}$ & $\begin{array}{l}\text { Rasio Profitabilitas ialah kemampuan } \\
\text { manajemen untuk memperoleh laba. } \\
\text { Untuk memperoleh laba di atas rata- } \\
\text { rata, manajemen harus mampu } \\
\text { meningkatkan pendapatan (revenue). }\end{array}$ & ROE $=\frac{\text { Laba Bersih }}{\text { Total Ekuitas }}$ \\
\hline $\begin{array}{l}\text { Dividen } \\
\text { Payout } \\
\text { Ratio }\end{array}$ & $\begin{array}{l}\text { Kebijakan Dividen merupakan } \\
\text { keputusan untuk membagi laba yang di } \\
\text { peroleh perusahaan kepada pemegang } \\
\text { saham sebagai dividen atau akan } \\
\text { menahan dalam bentuk laba ditahan } \\
\text { untuk digunakan sebagai pembiayaan } \\
\text { investasi pada masa yang akan datang. }\end{array}$ & $\mathrm{DPR}=\frac{\text { Dividen }}{\text { Earning After Taxes }}$ \\
\hline
\end{tabular}


Hipotesis diuji dengan analisis regresi linier berganda menggunakan program SPSS, untuk menganalisis pengaruh variabel independen terhadap variabel dependen. Model regresi yang digunakan yaitu:

$$
\mathrm{Y}=\mathrm{a}+\mathrm{b}_{1} \mathrm{X}_{1}+\mathrm{b}_{2} \mathrm{X}_{2}+\mathrm{b}_{3} \mathrm{X}_{3}+\mathrm{e}
$$
Keterangan:
Y : Nilai Perusahaan
a : Konstanta
$\mathrm{X}_{1} \quad$ : Rasio Likuiditas
$\mathrm{X}_{2} \quad$ : Rasio Aktivitas
$\mathrm{X}_{3} \quad$ : Rasio Solvabilitas
$\mathrm{X}^{4} \quad$ :Rasio Profitabilitas
$\mathrm{B}_{1,2} \quad$ : Besaran koefisien regresi dari masing-masing variabel
e : error

\section{HASIL DAN PEMBAHASAN PENELITIAN}

\subsection{Uji Asumsi Klasik}

Uji asumsi klasik merupakan suatu persyaratan statistik yang harus di penuhi untuk analisis linier, hal ini bertujuan untuk mengetahui apakah data yang di teliti telah memenuhi syarat kelayakan dalam penelitian. Syarat uji asumsi klasik yang harus di penuhi model regresi linier berganda yaitu : uji normolitas, uji multikolonieritas, uji autokolerasi, dan uji heteroskedastisitas.

1. Uji Normalitas

Uji normalitas bertujuan untuk menguji apakah model regresi residual memiliki distribusi normal, ada dua cara untuk mendeteksi apakah residual berdistribusi normal atau tidak normal dengan melihat analisis grafik histogram, normal probability plot, dan uji Kolmogorov Smirnov.

a. Grafik Histogram

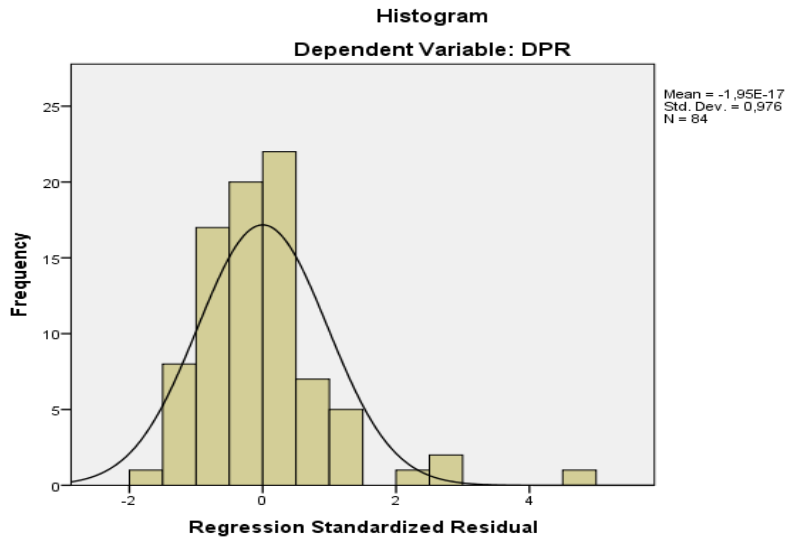

Dari grafik histogram pada gambar 2 diatas dapat dilihat bahwa grafik histogram memperlihatkan pola distribusi normal dimana garis kurva cenderung simetri (U). 
b. Normal Probability Plot

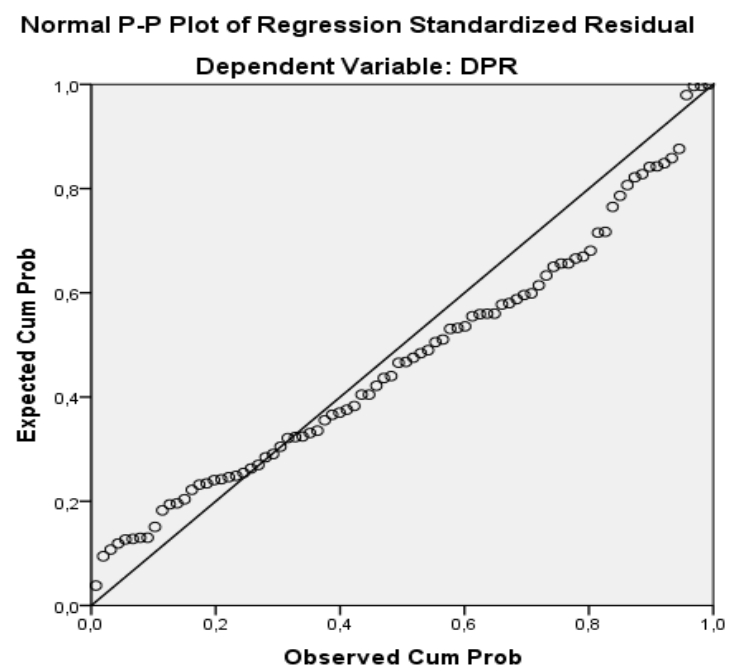

Dari grafik Normal Probability Plot berdasarkan gambar 3 diatas dapat dilihat bahwa titiktitik menyebar disekitaran garis diagonal. Maka dapat disimpulkan bahwa berdistribusi normal.

2. Uji Kolmogorov Smirnov

\section{One-Sample Kolmogorov-Smirnov Test}

\begin{tabular}{|c|c|c|}
\hline & & $\begin{array}{c}\text { Unstandardized } \\
\text { Residual }\end{array}$ \\
\hline $\begin{array}{l}\text { N } \\
\text { Normal Parameters }{ }^{a, b} \\
\text { Most Extreme Differences } \\
\text { Kolmogorov-Smirnov Z } \\
\text { Asymp. Sig. (2-tailed) }\end{array}$ & $\begin{array}{l}\text { Mean } \\
\text { Std. Deviation } \\
\text { Absolute } \\
\text { Positive } \\
\text { Negative }\end{array}$ & $\begin{array}{r}84 \\
, 0000000 \\
, 30282264 \\
, 124 \\
, 124 \\
-, 078 \\
1,140 \\
, 149\end{array}$ \\
\hline
\end{tabular}

a. Test distribution is Normal.

b. Calculated from data.

Sumber : Data Diolah

Dari hasil Uji Normalitas diketahui data dalam model regresi berdistribusi normal, karena signifikan lebih besar 0.05. Dimana nilai Asymp. Sig. (2-tailed) tersebut 0.149>0.05 dinyatakan data tersebut berdistribusi secara normal.

\section{Uji Multikolinieritas}

Uji multikolonieritas digunakan untuk mendeteksi ada tidaknya multikolonieritas di dalam model regresi tersebut dapat dilihat dari nilai Tolerance dan variance inflation factor, Model regresi yang baik seharusnya tidak terjadi korelasi diantara variabel independen. Untuk mendeteksi ada tidaknya korelasi multikolonieritas dalam model regresi dapat dilihat dari nilai Tolerance dan Variance Inflation Factor, pengambilan keputusan yaitu nilai VIF $\leq 10$ dan nilai Tolerance $\geq 0,10$ maka regresi bebas dari multikolonieritas. 


\section{Hasil Uji Multikolonieritas}

\begin{tabular}{|c|c|c|c|}
\hline \multirow{2}{*}{\multicolumn{2}{|c|}{ Model }} & \multicolumn{2}{|c|}{$\begin{array}{c}\text { Collinearity } \\
\text { Statistics }\end{array}$} \\
\hline & & $\begin{array}{c}\text { Toleran } \\
\text { ce }\end{array}$ & VIF \\
\hline \multirow{5}{*}{1} & $\begin{array}{l}\text { (Constan } \\
\text { t) }\end{array}$ & & \\
\hline & QR & ,451 & 2,218 \\
\hline & TATO & ,725 & 1,379 \\
\hline & DAR & ,432 & 2,313 \\
\hline & ROE & ,973 & 1,027 \\
\hline
\end{tabular}

a. Dependent Variable: DPR Sumber : Data Diolah

Melalui nilai Tolerance dan VIF diatas dapat diperoleh semua variabel memiliki nilai Tolerance $\geq 0,10$ dan VIF $\leq 10$. Maka dapat disimpulkan bahwa tidak terdapat multikolinearitas di antara variabel independen.

4. Uji Heteroskedastisitas

Uji Heteroskedastisitas berguna untuk menguji apakah model regresi terjadi ketidaksamaan variance dari residual satu pengamatan ke pengamatan yang lain, model regresi yang baik adalah tidak terjadi heteroskedastisitas. Uji heteroskedastisitas pada penelitian ini menggunakan grafik scatterplot dan Uji Glejser.

a. Grafik scatter plot

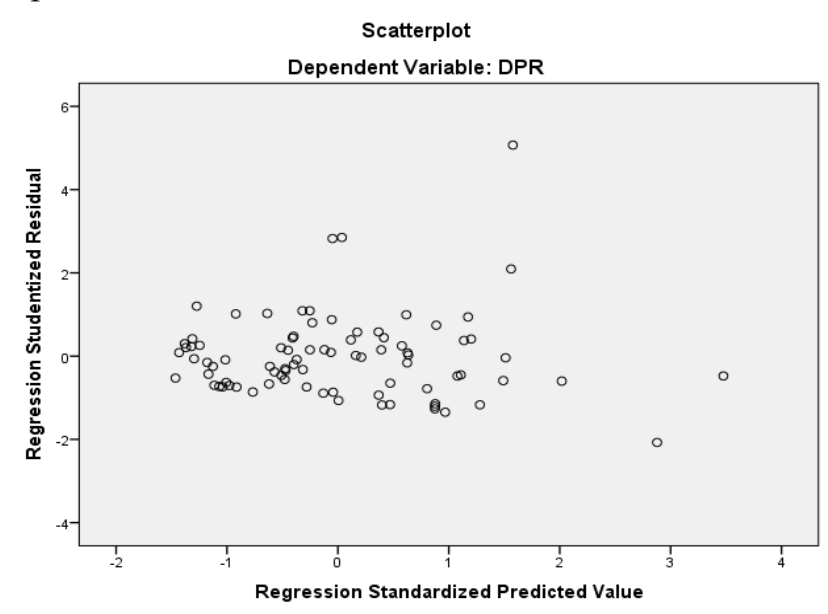

Berdasarkan Gambar tersebut Hasil pengujian Scatterplot setelah transformasi diatas terlihat bahwa titik-titk (plot) menyebar secara acak, baik diatas maupun di bawah angka nol (0) pada sumbu Y, tidak berkumpul di satu tempat, oleh karena itu berdasarkan uji Heteroskedastisitas dengan metode analisis grafik dinyatakan tidak terjadi gejala Heteroskedastisitas. 
b. Uji Glejser

\begin{tabular}{|c|c|c|c|c|c|c|}
\hline \multirow{3}{*}{ Mod } & & \multicolumn{3}{|c|}{ Coefficients $^{\mathrm{a}}$} & \multirow{3}{*}{$\mathrm{T}$} & \multirow{3}{*}{ Sig. } \\
\hline & & \multicolumn{2}{|c|}{ Unstandardized Coefficients } & Standardized & & \\
\hline & & B & Std. Error & Beta & & \\
\hline \multirow{5}{*}{1} & (Constant) & ,295 & ,138 & & 2,149 & ,035 \\
\hline & QR & ,013 & ,038 & , 056 & ,351 & ,726 \\
\hline & TATO &,- 068 & ,035 &,- 237 & $-1,959$ & ,054 \\
\hline & DAR &,- 075 & ,200 &,- 061 &,- 377 & ,707 \\
\hline & ROE & ,076 & ,096 & ,087 & ,795 & ,429 \\
\hline
\end{tabular}

a. Dependent Variable: ABS_RES_1

Berdasarkan hasil uji Glejser diatas menunjukkan nilai signifikan dari variabel Rasio Likuiditas memiliki nilai signifikan 0,726, Rasio Aktivitas memiliki nilai signifikan 0,054, Rasio Solvabilitas memiliki nilai signifikan 0,707, dan Rasio Profitabilitas memiliki nilai signifikan 0,429 . Karena nilai signifikan dari ketiga variabel lebih besar dari 0.05 atau 5\% maka dapat di simpulkan bahwa hasil uji glejser menunjukkan tidak terjadi masalah heteroskedastisitas.

\section{Uji Autokorelasi}

Uji Autokorelasi digunakan untuk menguji apakah dalam sebuah model regresi linier ada korelasi antara kesalahan pengganggu pada periode $t$ dengan kesalahan pengganggu pada periode $t-1$ (periode sebelumnya). Salah satu ukuran dalam menentukan ada tidaknya masalah Autokorelasi dengan Uji Durbin-Watson(DW).

Hasil Uji Autokorelasi Model Summaryb

\begin{tabular}{|l|r|r|r|r|r|}
\hline Model & $\mathrm{R}$ & $\mathrm{R}$ Square & $\begin{array}{c}\text { Adjusted } \mathrm{R} \\
\text { Square }\end{array}$ & $\begin{array}{c}\text { Std. Error of the } \\
\text { Estimate }\end{array}$ & Durbin-Watson \\
\hline 1 &, $375^{\mathrm{a}}$ &, 141 &, 097 &, 3103944 & 2,116 \\
\hline
\end{tabular}

a. Predictors: (Constant), ROE, DAR, TATO, QR

b. Dependent Variable: DPR

Sumber : Data Diolah

Berdasarkan Tabel 4, Hasil Uji Durbin Watson menunjukan bahwa nilai Durbin Watson 2,116 Sedangkan dalam tabel DW "K" $=4$. pengujian $\mathrm{du}<\mathrm{dw}<4-\mathrm{du}$. Nilai dl dan du dalam penelitian ini dengan jumlah 5 variabel dan 84 sampel adalah nilai $\mathrm{dl}=1,5472$ dan nilai $\mathrm{du}=1,7462$. Maka hasil pengukurannya adalah $1,7462<2,116<(4-1,7462)$ adalah 2,2538 Sehingga dapat di simpulkan bahwa $\mathrm{H}_{0}$ diterima yaitu tidak ada autokorelasi dalam model regresi penelitian ini dan $\mathrm{H}_{\mathrm{a}}$ ditolak.

\subsection{Uji Regresi Linear Berganda}

\begin{tabular}{|c|c|c|c|c|c|c|c|c|}
\hline \multirow{3}{*}{\multicolumn{2}{|c|}{ Model }} & \multicolumn{4}{|c|}{ Coefficients $^{\mathrm{a}}$} & \multirow{3}{*}{ Sig. } & \multirow{2}{*}{\multicolumn{2}{|c|}{$\begin{array}{l}\text { Collinearity } \\
\text { Statistics }\end{array}$}} \\
\hline & & \multicolumn{2}{|c|}{$\begin{array}{l}\text { Unstandardized } \\
\text { Coefficients }\end{array}$} & \multirow{2}{*}{$\begin{array}{c}\text { Standardized } \\
\text { Coefficients } \\
\text { Beta }\end{array}$} & \multirow[t]{2}{*}{$\mathrm{T}$} & & & \\
\hline & & $\mathrm{B}$ & Std. Error & & & & Tolerance & VIF \\
\hline & (Constant) & ,268 & ,203 & & 1,322 & ,190 & & \\
\hline & QR & ,086 & ,055 & 241 & 1,554 & ,124 & ,451 & 2,218 \\
\hline 1 & TATO &,- 084 & ,054 &,- 189 & $-1,546$ & ,126 & ,725 & 1,379 \\
\hline & DAR & ,073 & ,292 & ,039 & ,249 & ,804 & ,432 & 2,313 \\
\hline & ROE & ,279 & , 139 & ,212 & 2,007 & ,048 & ,973 & 1,027 \\
\hline
\end{tabular}

a. Dependent Variable: DPR

berikut:

Berdasarkan Tabel 6 diatas maka dapat diperoleh persamaan regresi Linier Berganda sebagai

$\mathrm{DPR}=0,268+0,086 \mathrm{QR}-0,084 \mathrm{TATO}+0,073 \mathrm{DAR}+0,279 \mathrm{ROE}$

Hasil Interpretasi dari regresi tersebut sebagai berikut : 
1. Nilai konstanta (a) sebesar 0,268, artinya jika nilai variabel Rasio Likuiditas (QR), RasioAktivitas (TATO), Rasio Solvabilitas (DAR), dan Rasio Profitabilitas (ROE) dianggap konstan makaDividend Payout Ratio adalah 0,268.

2. Nilai koefisien regresi Rasio Likuiditas (QR) sebesar 0,086 artinya bahwa setiap kenaikan variabel Rasio Likuiditas (QR) sebesar 1\% maka akan terjadi kenaikan Dividend Payout Ratio sebesar 8,6\% dengan asumsi variabel lain dianggap konstan.

3. Nilai Koefisien regresi Rasio Aktivitas (TATO) adalah sebesar -0,084 artinya bahwa setiap kenaikan variabel Rasio Aktivitas (TATO) sebesar 1\% maka akan terjadi penurunan Dividend Payout Ratio sebesar 8,4\% dengan asumsi variabel lain dianggap konstan.

4. Nilai Koefisien regresiRasio Solvabilitas (DAR) adalah sebesar 0,073 artinya bahwa setiap kenaikan variabel Rasio Solvabilitas (DAR) sebesar 1\% maka akan terjadi kenaikan Dividend Payout Ratio sebesar 7,3\% dengan asumsi variabel lain dianggap konstan.

5. Nilai Koefisien regresi Rasio Profitabilitas (ROE) adalah sebesar 0,279 artinya bahwa setiap kenaikan variabel Profitabilitas (ROE) sebesar 1\% maka akan terjadi kenaikan Dividend Payout Ratio sebesar 27,9\% dengan asumsi variabel lain dianggap konstan.

\subsection{Koefisien Determinasi}

Koefisien determinasi digunakan untuk mengukur seberapa besar kemampuan pengaruh variabel bebas dapat menjelaskan variabel terikat.koefisien determinasi $\left(\mathrm{R}^{2}\right)$ semakin besar maka semakin baik kemampuan variabel bebas $(\mathrm{X})$ menerangkan variabel terikat $(\mathrm{Y})$.

\section{Hasil Uji Koefisien Determinasi $\left(R^{2}\right)$}

\begin{tabular}{|l|r|r|r|r|r|}
\hline Model & $\mathrm{R}$ & $\mathrm{R}$ Square & $\begin{array}{c}\text { Adjusted R } \\
\text { Square }\end{array}$ & $\begin{array}{c}\text { Std. Error of the } \\
\text { Estimate }\end{array}$ & Durbin-Watson \\
\hline 1 &, $375^{\mathrm{a}}$ &, 141 &, 097 &, 3103944 & 2,116 \\
\hline
\end{tabular}

a. Predictors: (Constant), ROE, DAR, TATO, QR

b. Dependent Variable: DPR

Berdasarkan Tabel 7, diatas menunjukan bahwa nilai Adjusted $\mathrm{R}^{2}$ yang diperoleh adalah 0,097 atau sama dengan 9,7\% variabel dependen (Dividend Payout Ratio) dapat dijelaskan oleh variasi dari variabel independen yaitu: Likuiditas, Aktivitas, Solvabilitas, dan Profitabilitas. Sedangkan sisanya sebesar 90,3\% (100\% - 9,7\%) dipengaruhi oleh variabel lainnya.

\subsection{Pengujian Hipotesis Secara Simultan (Uji F)}

Uji F digunakan untuk menguji apakah variabel independen secara bersama- sama mempengaruhi variabel dependen.

\begin{tabular}{|c|c|c|c|c|c|c|}
\hline \multicolumn{7}{|c|}{$\begin{array}{c}\text { Hasil Uji F } \\
\text { ANOVA }^{\mathbf{a}}\end{array}$} \\
\hline Model & & Sum of Squares & Df & Mean Square & $\mathrm{F}$ & Sig. \\
\hline \multirow{3}{*}{1} & Regression & 1,247 & 4 & ,312 & 3,235 &, $016^{b}$ \\
\hline & Residual & 7,611 & 79 & ,096 & & \\
\hline & Total & 8,858 & 83 & & & \\
\hline
\end{tabular}

a. Dependent Variable: DPR

a. Predictors: (Constant), ROE, DAR, TATO, QR

Dari tabel 8, di atas dapat diketahui bahwa secara simultan atau bersama sama (Uji F) variabel independen berpengaruh dan signifkan terhadap variabel dependen. Hal ini dapat dibuktikan dari nilai $F_{\text {hitung }}$ sebesar 3,235 dengan niai signifikan 0,016 sedangkan $F_{\text {tabel }}$ sebesar 2,49 dengan signifikan 0,05. Dengan demikian dapat dilihat bahwa $F_{\text {hitung }} \geq F_{\text {tabel }}$ atau signifikan $3,235 \geq 2,49$ dan $0.016 \leq 0,05$. Sehingga $\mathrm{H}_{\mathrm{o}}$ ditolak dan $\mathrm{H}_{\mathrm{a}}$ di terima dimana Rasio Likuiditas, Rasio Aktivitas, Rasio Solvabilitas, dan Rasio Profitabilitas secara simultan berpengaruh dan signifikan terhadapDividend Payout Ratiopada 
perusahaan sektorTrade, Service, and Investment yang terdaftar di Bursa Efek Indonesia periode 20152018.

\section{Pengujian Hipotesis Secara Parsial (Uji t)}

Uji t dilakukan untuk mengetahui pengaruh masing- masing atau secara parsial variabel independen mempengaruhi variabel dependen.

\section{Hasil Uji t}

\begin{tabular}{|c|c|c|c|c|c|c|}
\hline \multirow{2}{*}{\multicolumn{2}{|c|}{ Model }} & \multicolumn{2}{|c|}{$\begin{array}{l}\text { Unstandardized } \\
\text { Coefficients }\end{array}$} & $\begin{array}{l}\text { Standardized } \\
\text { Coefficients }\end{array}$ & \multirow[t]{2}{*}{$\mathrm{T}$} & \multirow[t]{2}{*}{ Sig. } \\
\hline & & $\mathrm{B}$ & Std. Error & Beta & & \\
\hline \multirow{5}{*}{1} & (Constant) & ,268 & ,203 & & 1,322 & , 190 \\
\hline & QR & ,086 & ,055 & ,241 & 1,554 & ,124 \\
\hline & TATO &,- 084 & ,054 &,- 189 & $-1,546$ & ,126 \\
\hline & DAR & ,073 & ,292 & ,039 & ,249 & ,804 \\
\hline & ROE & ,279 & ,139 & ,212 & 2,007 & ,048 \\
\hline
\end{tabular}

Berdasarkan Tabel 9, maka pengaruh masing-masing variabel Rasio Likuiditas, Rasio Aktivitas, Rasio Solvabilitas, dan Rasio Profitabilitas secara parsial terhadap Dividend Payout Ratiodapat dilihat dari arah tanda dan tingkat signifikan (Probabilitas). Hasil pengujian hipotesis masing-masing variabel independen secara parsial terhadap variabel dependen dapat dianalisis sebagai berikut:

1. Variabel Rasio Likuiditas(QR) mempunyai nilai $t_{\text {hitung }} 1,554$ dengan nilai signifikan 0,124 . Sedangkan nilai $t_{\text {tabel }}$ adalah sebesar 1,99006 dengan signifikan 0,05. Sehingga kesimpulannya adalah $t_{\text {hitung }} \leq t_{\text {tabel }}$ yaitu $1,554 \leq 1,99006$ maka keputusannya adalah $\mathrm{H}_{\mathrm{o}}$ diterima dan $\mathrm{H}_{\mathrm{a}}$ ditolak, artinya variabel Rasio Likuiditas (QR) secara parsial tidak berpengaruh dan tidak signifikan terhadap Dividend Payout Ratiopada perusahaan sektor Trade, Service and Investment yang terdaftar di Bursa Efek Indonesia periode 2015-2018.

2. Variabel Rasio Aktivitas (TATO) mempunyai nilai thitung $-1,546$ dengan tingkat signifikan 0,126. Sedangkan nilai $t_{\text {tabel }}$ adalah sebesar 1,99006 dengan signifikan 0,05. Sehingga kesimpulannya adalah $-\mathrm{t}_{\text {hitung }} \leq \mathrm{t}_{\text {tabel }}$ yaitu $-1,546 \leq 1,99006$ maka keputusannya adalah $\mathrm{H}_{\mathrm{o}}$ diterima dan $\mathrm{H}_{\mathrm{a}}$ ditolak, artinya variabel Rasio Aktivitas (TATO) secara parsial tidak berpengaruh dan tidak signifikan terhadap Dividend Payout Ratio pada perusahaan sektor Trade, Serviceand Investment yang terdaftar di Bursa Efek Indonesia periode 2015-2018.

3. Variabel Rasio Solvabilitas (DAR) mempunyai nilai $t_{\text {hitung }} 0,249$ dengan tingkat signifikan 0,804 sedangkan nilai tabel adalah sebesar 1,99006 dengan signifikan 0,05 sehingga kesimpulannya adalah $\mathrm{t}_{\text {hitung }} \leq \mathrm{t}_{\text {tabel }}$ yaitu $0,249 \leq 1,99006$ maka keputusannya adalah $\mathrm{H}_{\mathrm{o}}$ diterima dan $\mathrm{H}_{\mathrm{a}}$ ditolak, artinya variabel Rasio Solvabilitas (DAR) secara parsial tidak berpengaruh dan tidak signifikan terhadap Dividend Payout Ratio pada perusahaan sektor Trade, Service and Investment yang terdaftar di Bursa Efek Indonesia periode 2015-2018.

4. Variabel Rasio Profitabilitas (ROE) mempunyai nilai thitung 2,007 dengan tingkat signifikan 0,48 sedangkan nilai tabel adalah sebesar 1,99006 dengan signifikan 0,05 sehingga kesimpulannya adalah $\mathrm{t}_{\text {hitung }} \geq \mathrm{t}_{\text {tabel }}$ yaitu $2,007 \geq 1,99006$ maka keputusannya adalah $\mathrm{H}_{\mathrm{o}}$ ditolak dan $\mathrm{H}_{\mathrm{a}}$ diterima, artinya variabel Rasio Profitabilitas (ROE) secara parsial berpengaruh positif dan signifikan terhadap Dividend Payout Ratio pada perusahaan sektor Trade, Serviceand Investment yang terdaftar di Bursa Efek Indonesia periode 2015-2018. 


\section{KESIMPULAN}

Berdasarkan hasil penelitian dan pembahasan tentang pengaruh Likuiditas, Aktivitas, Solvabilitas, dan Profitabilitas terhadap Dividend Payout Ratio dapat ditarik kesimpulan bahwa:

1. Rasio Likuiditas (QR) secara parsial tidak berpengaruh dan tidak signifikan terhadap Dividend Payout Ratio pada perusahaan sektor Trade, Service, and Investment yang terdaftar di Bursa Efek Indonesia periode $2015-2018$, dengan nilai $t_{\text {hitung }} \leq t_{\text {tabel }}(1,554 \leq 1,66437)$ dan signifikan 0,124 .

2. Rasio Aktivitas (TATO) secara parsial tidak berpengaruh dan tidak signifikan terhadap Dividend Payout Ratio pada perusahaan sektor Trade, Service, and Investment yang terdaftar di Bursa Efek Indonesia periode 2015-2018, dengan nilai - $t_{\text {hitung }} \leq t_{\text {tabel }}(-1,546 \leq 1,66437)$ dan signifikan 0,126.

3. Rasio Solvabilitas (DAR) secara parsial tidak berpengaruh dan tidak signifikan terhadap Dividend Payout Ratio pada perusahaan sektor Trade, Service, and Investment yang terdaftar di Bursa Efek Indonesia periode 2015-2018, dengan nilai perbandingan $t_{\text {hitung }} \leq t_{\text {tabel }}(0,249 \leq$ 1,66437) dan signifikan 0,804.

4. Rasio Profitabilitas (ROE) secara parsial berpengaruh dan signifikan terhadap Dividend Payout Ratio pada perusahaan sektor Trade, Service, and Investment yang terdaftar di Bursa Efek Indonesia periode 2015-2018, dengan nilai perbandingan $t_{\text {hitung }} \geq t_{\text {tabel }}(2,007 \geq 1,66437)$ dan signifikan 0,048 .

5. Hasil nilai $F_{\text {hitung }}$ sebesar 3,235 dengan nilai signifikan 0,016 sedangkan $F_{\text {tabel }}$ sebesar 2,49 dengan signifikan 0,05 , dengan demikian dapat dilihat bahwa $F_{\text {hitung }} \geq F_{\text {tabel }}$ atau signifikan $3,235 \geq 2,49$ dan $0,016 \leq 0,05$ sehingga $H_{a}$ diterima dimana Rasio Likuiditas $(\mathrm{QR})$, Rasio Aktivitas (TATO), Rasio Solvabilitas (DAR), dan Rasio Profitabilitas (ROE) secara simultan berpengaruh dan signifikan terhadap Dividend Payout Ratio pada perusahaan sektor Trade Service and Investment yang terdaftar di Bursa Efek Indonesia periode 2015-2018.

\section{REFERENSI}

Ari Ambarwati, Sri Dwi. 2010. Manajemen Keuangan Lanjutan. Cetakan pertama. Yogyakarta: Graha Ilmu.

Fahmi, Irham. 2016. Pengantar Perbankan dan Teori Aplikasi. Cetakan Pertama. Bandung: Alfabeta. Gumanti, Tatang Ary. 2013. Kebijakan Dividen. Yogyakarta: UPP STIM YKPN.

Ghozali, Imam. 2017. Aplikasi Analisis Multivariete. Cetakan Kedelapan. Semarang: Universitas Diponegoro.

Hanafi, Mamduh. Dan Halim, Abdul. 2012. Analisis Laporan Keuangan.Cetakan kedua. Yogyakarta: UPP STIM YKPN

Hani, Syafrida. 2015. Teknik Analisa Laporan Keuangan. Medan: UMSUPRESS.

Harahap,Sofyan Syafri. 2015. Analisis Krisis atas Laporan Keuangan. Cetakan kedua belas. Jakarta: PT. Rajagrafindo Persada.

Harmono. 2018. Manajemen Keuangan. Cetakan Keempat. Jakarta: PT Bumi Aksara.

Haryatih. 2015. Pengaruh Growth, Cash Position, Liquidity,Solvability, dan Profitability, Terhadap Dividen Payout Ratio. Jurnal Akutansi dan Keuangan, vol 4, nomor 2, ISSN: 2252-7141.

Hery. 2015. Analisis Laporan Keuangan (Pendekatan Rasio Keuangan). Jakarta: Caps Publising. Jumingan. 2014. Analisis Laporan Keuangan. Cetakan kelima. Jakarta: PT.Bumi Aksara.

Kamaludin. Dan Indriani, Rini. 2012. Manajemen Keuangan (Konsep Dasar dan Penerapannya). Cetakan kedua.Bandung: CV.Mandar Maju.

Kasmir. 2015. Analisis Laporan Keuangan. Cetakan Kelapan. Jakarta: PT.Raja Grafindo Persada.

Kodrat, Davit Sukardi. Dan Indonanjaya, Kurniawan. 2010. Manajemen Investasi. Cetakan Pertama. Yogyakarta: Graha Ilmu.

Mulyawan, Setia. 2015. Manajemen Keuangan. Cetakan pertama. Bandung: CV Pustaka Setia.

Munawir. 2014. Analisis Laporan Keuangan. Cetakan Ketiga. Yogyakarta: Liberty Yogyakarta. 
Purnami, K. D. A. Dan Artini, L. G. S. 2016. Pengaruh Investment Opportunity Set, Total Asset Turn Over dan Sales Growth Terhadap Kebijakan Dividen. E-Jurnal Manajemen Unud, vol 5, nomor 2, ISSN: 2302-8912.

Prihadi, Toto. 2012. Praktis Memahami Laporan Keuangan Sesuai IFRS \& PSAK. Cetakan Kedua. Jakarta: PPM.

Raharjaputra, Hendra. 2011. Manajemen Keuangan dan Akutansi. Cetakan Pertama. Jakarta: Salemba Empat.

Riyanto, Bambang. 2010. Dasar-dasar Pembelanjaan Perusahaan. Cetakan ketiga. Yogyakarta: BPFE.

Rodoni, Ahmad. Dan Ali, Herni. 2014. Manajemen Keuangan Modern. Jakarta: Mitra Wacana Media.

Sarmento, J. D. C. Dan Dana, Made. 2016. Pengaruh Return on Equity, Current Ratio, and Earning Per Share Terhadap Kebijakan Dividen Pada Perusahaan Keuangan. E-Jurnal Manajemen Unud, vol 5, nomor 7, ISSN: 2302-8912.

Sartono, Agus. 2010. Manajemen Keuangan Teori dan Aplikasi. Cetakan keempat. Yogyakarta: BPFE.

Subramanyam. dan Wild, John. 2010. Analisis Laporan Keuangan. Jakarta: Salemba Empat.

Sudana, I.Made. 2015. Manajemen Keuangan Perusahaan. Jakarta: Erlangga.

Sugiono, Arief. Dan Untung, Edi. 2016. Panduan Praktis Dasar Analisis Laporan Keuangan. Jakarta: PT Grasindo.

Sugiono. 2017. Metode Penelitian Kuantitatif, Kualitati, dan R\&D. Bandung: Alfabeta.

Sjahrial, Dermawan. dan Purba, Djahotman. 2013. Analisis Laporan Keuangan. Jakarta: Mitra Wacana Media.

Syamsuddin, Lukman. 2018. Manajemen Keuangan Perusahan. Cetakan Kedua belas. Jakarta: PT Rajagrafindo Persada.

Utari, Dewi. dkk. 2014. Manajemen Keuangan. Jakarta: Mitra Wacana Media.

Van Horne, James. Dan Wachowicz, John. 2012. Prinsip-Pinsip Manajemen Keuangan. Jakarta: Salemba Empat.

Wijaya, David. 2017. Manajemen Keuangan (Konsep dan Penerapannya). Jakarta: PT Grasindo.

Yasa, K. D. M. Dan Wirawati, N. G. P. 2016. Pengaruh Net Profit Margin, Current Ratio, dan Debt to Equity Ratio Pada Dividend Payout Ratio. E-Jurnal Akutansi Universitas Udayana, 16.2, 921950. 